\title{
PEMAHAMAN SISWA SMP TERHADAP KONSEP PEMBAGIAN PECAHAN BERDASAR TUGAS PENGAJUAN SOAL ANALOGIS
}

\author{
Erina Aprilia Susanti \\ Pendidikan Matematika, FMIPA, Universitas Negeri Surabaya, email: erina.17030174069@mhs.unesa.ac.id
}

\author{
Abdul Haris Rosyidi \\ Pendidikan Matematika, FMIPA, Universitas Negeri Surabaya, email: abdulharis@unesa.ac.id
}

\begin{abstract}
Abstrak
Seseorang dikatakan paham konsep bila mampu mengenali konsep tersebut di setiap konteks. Salah satu cara untuk mengeksplorasi pemahaman konsep yaitu dengan pengajuan soal analogis. Berdasarkan hal tersebut maka penelitian ini dilakukan untuk mengetahui bagaimana pemahaman siswa terhadap konsep pembagian pecahan berdasar tugas pengajuan soal analogis. Penelitian ini merupakan penelitian deskriptif kualitatif dengan subjek tiga siswa SMP kelas VIII. Pemilihan Subjek dilakukan dengan metode variasi maksimal ditentukan berdasarkan ketepatan pengajuan soal. Instrumen penelitian ini adalah wawancara berbasis tes pemahaman konsep. Data dianalisis menggunakan tiga komponen pemahaman konsep yaitu penerjemahan, penafsiran, dan ekstrapolasi. Hasil penelitian menunjukan bahwa pemahaman konsep pembagian pecahan siswa SMP dalam tugas pengajuan soal analogis, yaitu pada komponen penerjemahan hanya satu subjek yang mampu menjelaskan konsep pembagian pecahan yang digunakan dalam tugas pengajuan soal. Pada komponen penafsiran semua subjek mampu menyebutkan konsep matematika yang terdapat pada soal, namun tidak ada subjek yang mampu memahami hubungan antara perintah soal dengan jawaban pada contoh soal. Keterkaitan antara perintah soal dengan jawaban contoh soal dapat digunakan dalam penggunaan konsep pada tugas pengajuan soal, tetapi tidak ada subjek yang mampu memahami keterkaitan tersebut karena subjek tidak memiliki pemahaman yang memadai pada materi prasyarat. Pada komponen ekstrapolasi terdapat satu subjek yang mampu mengajukan soal sesuai dengan konteks dan konsep pembagian pecahan, namun satu subjek lainnya mengalami kesalahan pada salah satu tugas pengajuan soal karena tugas pengajuan soal yang dikerjakan tidak sesuai konsep pecahan. Terdapat satu subjek yang tidak memenuhi ketiga komponen pemahaman, hal tersebut karena subjek hanya menulis ulang jawaban contoh soal ke dalam tugas pengajuan soal. Oleh karena itu penting bagi guru untuk melatih kemampuan menggunakan analogi agar pemahaman konsep siswa semakin mendalam mengenai materi yang sedang diajarkan, memberikan tugas pengajuan soal analogi juga membantu guru mengetahui pemahaman siswa pada materi yang sedang diajarkan dan materi yang telah diajarkan sebelumnya.
\end{abstract}

Kata Kunci: Pemahaman Konsep, Pengajuan Soal Analogis, Pembagian Pecahan.

\begin{abstract}
A person is said to understand the concept when able to recognize the concept in every context. One way to explore understanding concepts is by filing analogical questions. Based on this, this research was conducted to find out how students understand the concept of fractional division based on the task of filing analogical questions. This research is a qualitative descriptive research with the subjects of three junior high school students in grade VIII. Subject selection is done by maximum variation method determined based on the accuracy of the question submission. This research instrument is an interview-based concept comprehension test. The data were analyzed using three components of concept understanding, namely translation, interpretation, and extrapolation. The results showed that understanding the concept of fractional division of junior high school students in the task of filing analogical questions, namely in the translation component only one subject is able to explain the concept of fraction division used in the task of filing the question. In the interpretation component all subjects are able to mention the mathematical concepts contained in the problem, but no subject is able to understand the relationship between the command of the question and the answer to the sample problem. The linkage between the question command and the answer to the sample question can be used in the use of concepts on the task of submitting the question, but no subject is able to understand the association because the subject does not have an adequate understanding of the prerequisite material. In the extrapolation component there is one subject that is able to ask questions in accordance with the context and concept of fractional division, but one other subject has an error in one of the task submissions because the task of submitting the problem is not in accordance with the concept of fractions. There is one subject that does not meet all three components of understanding, which is because the subject simply
\end{abstract}


rewrites the answer to the sample question into the task of filing the question. Therefore it is important for teachers to practice the ability to use analogies so that the students' concept understanding is more in-depth about the material being taught, giving the task of submitting analogy questions also helps the teacher know the students' understanding of the material being taught and the material that has been taught before.

Keywords: Conceptual Understanding, Analogist Problem Submission, Fractional Division.

\section{PENDAHULUAN}

Pemahaman terhadap konsep merupakan salah satu tujuan pembelajaran matematika. Permendikbud No. 24 Tahun 2016 menekankan pentingnya pemahaman siswa terhadap materi pembelajaran matematika yang dituangkan dalam kompetensi dasar yang dibebankan. National Council of Teaching Mathematics (2000) mengemukakan pentingnya pemahaman saat belajar matematika dengan menuntut siswa aktif membangun pengetahuan baru dari pengalaman dan pengetahuan sebelumnya. Hope (2006) menyatakan bahwa pemahaman matematika memiliki andil secara langsung untuk menemukan konsep-konsep di balik algoritma yang diterapkan, dengan demikian siswa dapat memformulasikan dan menerapkan di suatu situasi sehingga dapat memahami konsep-konsep matematika yang dipelajari.

Pemahaman adalah suatu proses yang terdiri dari kemampuan untuk menerangkan dan mengintepretasikan sesuatu, mampu memberikan gambaran, contoh dan penjelasan yang lebih luas dan memadai serta mampu memberikan uraian dan penjelasan (Mawaddah dan Maryanti, 2016). Menurut Carin dan Sund (dalam Susanto, 2013) pemahaman merupakan kemampuan untuk menerangkan dan mengintepretasikan sesuatu. Berdasarkan pendapat beberapa ahli dapat dinyatakan bahwa seseorang yang telah memperoleh pemahaman akan mampu menerangkan dan mengintepretasikan kembali apa yang telah ia terima.

Pemahaman individu dapat dicapai bila pengetahuannya dapat dikontruksi dan direkontruksi sendiri secara aktif (Racmawati, 2020). Menurut Bloom (dalam Hutama, 2014) komponen pemahaman konsep yaitu penerjemahan, penafsiran dan ekstrapolasi. Penerjemahan yaitu menerjemahkan konsepsi abstrak menjadi suatu model, kata kerja operasional yang digunakan adalah menerjemahkan, mengubah, mengilustrasikan, memberi definisi, dan menjelaskan kembali. Penafsiran yaitu kemampuan untuk mengenal dan memahami ide utama suatu komunikasi, kata kerja operasional yang digunakan adalah menginterpretasikan, membedakan, menjelaskan, dan menggambarkan. Ekstrapolasi yaitu menyimpulkan dari sesuatu yang telah diketahui, kata kerja operasional yang digunakan adalah memperhitungkan, menduga, menyimpulkan, meramalkan, membedakan, menentukan, dan mengisi.
Salah satu dimensi dari pemahaman adalah kemampuan mengenali dan menerapakan konsep dalam dunia nyata (Usiskin, 2012). Thompson dan Bleiler (2013) menamai dimensi pemahaman tersebut adalah uses. Uses menagih kemampuan menerapkan konsep dalam matematika ke dunia nyata, dan mengharapkan siswa mengembangkan model matematika untuk mendeskripsikan pemahaman matematis (Sulaiman dkk., 2019). Berdasarkan pendapat ini dapat disimpulkan bahwa menerapkan suatu konsep dalam kehidupan nyata merupakan implementasi dari pemahaman, maka dari itu dimensi uses dapat digunakan dalam mendeskripsikan pemahaman seseorang.

Dalam penelitian ini peneliti mendeskripsikan pemahaman melalui penerapan konsep dalam kehidupan nyata yaitu dengan pengajuan soal dan dianalisis menggunakan komponen pemahaman Bloom. Pada pembelajaran siswa dituntut mampu untuk mendefinisikan pengetahuannya, menjelaskan pengetahuannya, serta memperluas konsep yang telah diketahui. Menurut Tawil dkk. (2011) siswa yang telah memahami suatu konsep akan mampu memahami konsep tersebut walapun dalam bentuk yang berbeda yaitu dalam pengajuan soal.

Dalam pembelajaran, pengajuan soal merupakan teknik dari pemberian tugas. Dalam tugas pengajuan soal, siswa diminta untuk membuat soal, serta menyelesaikan soal yang telah dibuat. Menurut Siswono (2008) pengajuan soal ialah perumusan soal yang berkaitan dengan syarat-syarat pada soal yang telah dipecahkan dalam rangka pencarian alternatif pemecahan atau alternatif soal yang relevan. Pengajuan soal merupakan cara yang tepat untuk mengeksplorasi pemahaman konseptual, juga dapat digunakan untuk meneliti konsep yang dipahami siswa melalui alur cerita yang diajukan (Mestre, 2002). Indiarti (2005: 6) menyatakan bahwa:

"Pengajuan soal merupakan teknik dari metode pemberian tugas, dalam pemberian tugas pengajuan soal memberikan kesempatan pada siswa untuk menyelidiki informasi atau keterangan yang ada, kemampuan menyelidiki akan menentukan kemampuan siswa untuk mempertahankan pengetahuan dan menerapkan pengetahuan."

Tugas pengajuan soal merupakan cara yang tepat untuk meneliti pemahaman konsep yang telah dimiliki seseorang. Suatu konsep dalam matematika dapat mudah dipahami bila seseorang mampu menganalogikan konsep sederhana yang telah dipahami ke konsep abstrak yang 
memiliki hubungan, sehingga dapat menjadi bahan pertimbangan untuk diperbandingkan (Alghadari dan Kusuma, 2018). Analogi adalah membandingkan kesamaan atau perbedaan antara dua hal atau lebih, sedangkan penalaran analogi merupakan proses penalaran yang berkaitan dengan analogi (Ningrum dan Rosyidi, 2013). Menurut Kristayulita (2015) analogi merupakan bagian dari penalaran induktif, selain itu analogi dapat dijadikan sebagai dasar penalaran serta digunakan sebagai dasar pengambilan sebuah kesimpulan dari kesamaankesamaan yang ada. Kapur (2015) menyatakan bahwa pada masa sekarang berpikir analogi merupakan hal yang penting dalam pembelajaran matematika khususnya untuk pemahaman konsep. Hal ini dibuktikan oleh peneliti empiris lintas disiplin berpendapat bahwa berpikir analogi penting untuk pembelajaran konsep-konsep yang abstrak (Kapur, 2015),

Analogi memiliki peran penting dalam menyumbang pemahaman seseorang terhadap prosedur baru yang mempunyai struktur yang mirip dengan prosedur yang ia kenali (Rosyidi, 2020). Halford (dalam Loc dan Uyen, 2014) menyatakan kemampuan analogi sebagai inti dari perkembangan kognitif. Berdasarkan pendapat para ahli maka analogi dapat membantu siswa dalam memahami suatu materi dengan mencari keserupaan sifat di antara materi yang dibandingkan, dapat mengukur aspek kognitif siswa, kemampuan siswa dalam mencari sifat yang berhubungan pada suatu konsep, dan mencari keserupaan di antara dua konsep yang sama atau berbeda.

Analogi dibagi menjadi dua macam yaitu Analogi Deklaratif dan Analogi Induktif. Analogi deklaratif merupakan metode untuk menjelaskan atau menegaskan sesuatu yang belum dikenal atau masih samar dengan sesuatu yang telah diketahui. Analogi induktif analogi yang disusun berdasarkan persamaan prinsip dari dua hal yang berbeda, selanjutnya ditarik kesimpulan bahwa apa yang terdapat pada hal pertama terdapat pula pada hal kedua (Mundiri, 2012). Dengan kemampuan analogis tinggi, siswa dapat memahami konsep dan menyelesaikan permasalahan matematika dengan lebih mudah, selain itu siswa dapat mengaitkan konsep yang dipelajari sekarang dengan konsep yang sudah dipelajari lebih dahulu (Mundiri, 2012). Pada penelitian ini menggunakan tipe analogi induktif dimana siswa diharapkan mampu untuk menyimpulkan dan menyusun soal berdasarkan persamaan struktur dari dua hal yang berbeda.

Menurut Hasimoto (dalam Park, 2018) aktivitas mengajukan soal dengan analogi dapat digunakan sebagai alat yang berguna untuk mendeskripsikan pemahaman. Kemampuan pengajuan soal terkait erat dengan pemahaman, pengetahuan melibatkan tugas-tugas kognitif, dimana individu diberikan suatu masalah, diidentifikasi, selanjutnya dipecahkan (Hasimoto dalam
Park, 2018). Untuk membangun masalah yang benar dan dapat dipecahkan, individu harus menggabungkan alur cerita yang tepat dengan objek dan peristiwa yang sesuai. Park (2018) menyatakan bahwa pengajuan soal analogis mengacu pada situasi, dimana proses pengajuan soal analogis dapat diwujudkan dengan menciptakan masalah baru yang serupa dengan masalah yang diberikan (masalah yang mendasari), setiap soal yang diajukan disesuaikan dengan konteks yang disajikan pada permasalahan dasar.

Dari penjelasan ahli mengenai pengajuan soal analogis maka dapat dinyatakan bahwa dengan tugas pengajuan soal analogis siswa dapat menemukan prinsip dari suatu konsep, memperluas konsep, dan mengembangkan konteks yang serupa. Komponen pemahaman yang sesuai dalam mendeskripsikan pemahaman konsep melalui tugas pengajuan soal berkonteks analogis yaitu komponen penafsiran. Dengan menggunakan komponen penafsiran peneliti dapat mengetahui pemahaman konsep pembagian pecahan melalui penjelasan siswa mengenai keterkaitan antara soal yang diajukan dengan informasi yang diberikan. Siswa yang memenuhi komponen penafsiran mencerminkan bahwa ia memahami ide utama dari tes yang diberikan.

Tidak dapat dipungkiri bahwa dalam pembelajaran matematika, materi pecahan salah satu topik penting bagi siswa sebagai dasar mempelajari aljabar dan materi lainnya, selain itu pentingnya menguasai materi pecahan karena dalam kehidupan sehari-hari materi pecahan sering digunakan (Aminah dkk., 2018). Kenyataanya masih banyak yang belum memahami materi pecahan (Yulianingsih dkk., 2018). Dalam kurikulum Indonesia, materi pecahan dipelajari pada kelas tiga sekolah dasar, dan kelas tujuh sekolah menengah pertama. Pada sekolah dasar, konsep pecahan diajarkan melalui contoh benda kongkrit, serta diajarkan konsep awal pembagian melalui operasi pengurangan. Materi pecahan kembali diajarkan pada SMP kelas tujuh semester satu, tujuan pembelajaran dilakukan untuk melatih daya nalar dan kemampuan memecahkan masalah yang berkaitan dengan kehidupan sehari-hari (Hariyani, 2016).

Pemahaman siswa terhadap pecahan belum memuaskan. Hal tersebut sejalan dengan penelitian yang dilakukan Bright (dalam Suwarto, 2018) berdasarkan hasil berbagai penelitian telah menemukan bahwa banyak siswa mengalami kesulitan memahami pecahan dan desimal. Penelitian lain mengenai pemahaman siswa terhadap pecahan juga dilakukan Unaenah dkk. (2019) mengemukakan bahwa pemahaman konsep matematis siswa pada materi pecahan masih rendah, sehingga masih ditemukan beberapa kesalahan dalam memahami konsep pecahan.

Penelitian mengenai pemahaman konsep telah banyak dilakukan, beberapa diantaranya yaitu penelitian yang 
dilakukan oleh Mulyani dkk. (2018) penelitian tersebut membahas tentang analisis kemampuan pemahaman matematika siswa SMP pada materi bentuk aljabar. Penelitian lain mengenai pemahaman konsep juga dilakukan oleh Hutama (2014) yang membahas pengaruh pendekatan problem posing terhadap pemahaman konsep matematika siswa.

Penelitian lain terkait pemahaman konsep khususnya topik pecahan juga telah banyak dilakukan oleh Ruslan dkk. (2019) yang mengkaji pemahaman konsep matematika siswa pada materi pecahan dengan memperhatikan gaya belajar visual. Selain itu Juliangkary dan Zulkifli (2018) melakukan penelitian untuk mengetahui pemahaman konsep materi pecahan pada siswa kelas VII. Penelitian lain terkait pemahaman konsep topik pecahan juga dilakukan oleh Unaenah, dkk. (2019) penelitian ini meneliti tentang pemahaman konsep materi pembagian pecahan dilihat dari tugas penyelesaian masalah.

Berdasarkan beberapa penelitian mengenai pemahaman khususnya pada materi pecahan belum ada yang melakukan penelitian dengan melihat pemahaman konsep siswa melalui tugas pengajuan soal analogis. Sehingga upaya-upaya untuk mengetahui konsep yang telah dimiliki siswa dapat melalui tugas pengajuan soal analogis. Oleh karena itu, peneliti tertarik untuk melakukan penelitian mengenai pemahaman siswa terhadap konsep pembagian pecahan berdasar tugas pengajuan soal analogis.

\section{METODE}

Penelitian ini merupakan penelitian deskriptif dengan pendekatan kualitatif. Bentuk penelitian deskriptif yang digunakan untuk memaparkan dan mendeskripsikan pemahaman siswa terhadap konsep pembagian pecahan secara mendalam berdasarkan pengajuan soal analogis yang diajukan. Subjek penelitian yaitu tiga siswa SMP kelas VIII. Pemilihan subjek dilakukan dengan metode variasi maksimal. Prosedur pemilihannya dilakukan tes terhadap 16 siswa, kemudian dilihat variasi jawaban yang ada. Variasi Maksimal ditentukan berdasarkan ketepatan pengajuan soal subjek: (1) Pengajuan Soal A Benar, pengajuan Soal B Benar (Subjek 1), (2) Pengajuan soal A benar, pengajuan soal B salah (Subjek 2), (3) Pengajuan soal A salah, pengajuan soal B salah (Subjek 3). Masingmasing variasi tersebut akan diambil satu sebagai subjek dengan mempertimbangkan kelengkapan jawabannya.

Instrumen yang digunakan dalam penelitian ini yaitu Tes Pemahaman Konsep (TPK) dan wawancara. TPK terdiri dari empat soal. Pada soal pertama berisi dua soal a dan $b$ yang diberikan kepada siswa untuk mengajukan soal, tiga soal lainnya diberikan dengan tujuan untuk mengetahui lebih dalam pemahaman konsep siswa. Berikut soal tes pemahaman konsep.

\section{Petunjuk}

1. Baca soal secara keseluruhan terlebih dahulu.

2. Selesaikan setiap soal berdasarkan kemampuanmu sendiri

3. Perhatikan contoh soal sebelum mengerjakan

4. Tuliskan jawaban soal di bawah "Penyelesaian".

\section{Contoh}

Buatlah soal cerita dalam kehidupan sehari-hari yang penyelesaiannya menggunakan $12-4$.

Penyelesaian:

Adit memiliki 12 buah permen. Empat permen Adit diberikan kepada Bayu. Berapa sisa permen Adit sekarang?

\section{Soal}

1. Buatlah soal cerita dalam kehidupan sehari-hari yang penyelesaiannya menggunakan operasi pembagian berikut.
a. $4 \div \frac{1}{2}$
b. $\frac{1}{2} \div \frac{1}{4}$

2. Ceritakan prosesmu dalam membuat soal cerita di nomor 1a ataupun 1b! Apakah kamu langsung menemukan soalnya atau lewat beberapa kali percobaan? Jika lewat beberapa kali percobaan ceritakan mulanya seperti apa, perubahannya bagaimana dan mengapa diubah?

3. Apakah kamu yakin bahwa soal cerita yang kamu buat benar (soal yang kamu ajukan sesuai permintaan)? Jelaskan!

4. Apakah contoh di atas membantumu dalam membuat soal cerita untuk menjawab soal nomor 1? Jelaskan!

Data hasil TPK dan wawancara dianalisis dengan menyesuaikan jawaban subjek berdasarkan komponen pemahaman konsep melalui tugas pengajuan soal analogis yang dikembangkan peneliti menurut komponen pemahaman konsep Benjamin Bloom dalam (Hutama, 2014), Jihad dan Rosyidi (2009), Shadiq (2009), dan Kilpatrik et al (Lestari dan Yudhanegara, 2015: 81).

Tabel 1. Komponen Pemahaman Konsep Berdasar Tugas

\begin{tabular}{|c|c|}
\hline $\begin{array}{l}\text { Komponen } \\
\text { pemahaman }\end{array}$ & Deskripsi \\
\hline Penerjemahan & $\begin{array}{l}\text { Mampu menjelaskan ulang konsep } \\
\text { yang telah dipelajari pada soal (materi } \\
\text { operasi pembagian pecahan) dan } \\
\text { contoh soal (materi operasi } \\
\text { pengurangan) secara lisan maupun } \\
\text { tulisan. }\end{array}$ \\
\hline Penafsiran & $\begin{array}{l}\text { Mampu memahami hubungan antara } \\
\text { perintah soal dengan jawaban contoh } \\
\text { soal (materi pengurangan) yang akan }\end{array}$ \\
\hline
\end{tabular}




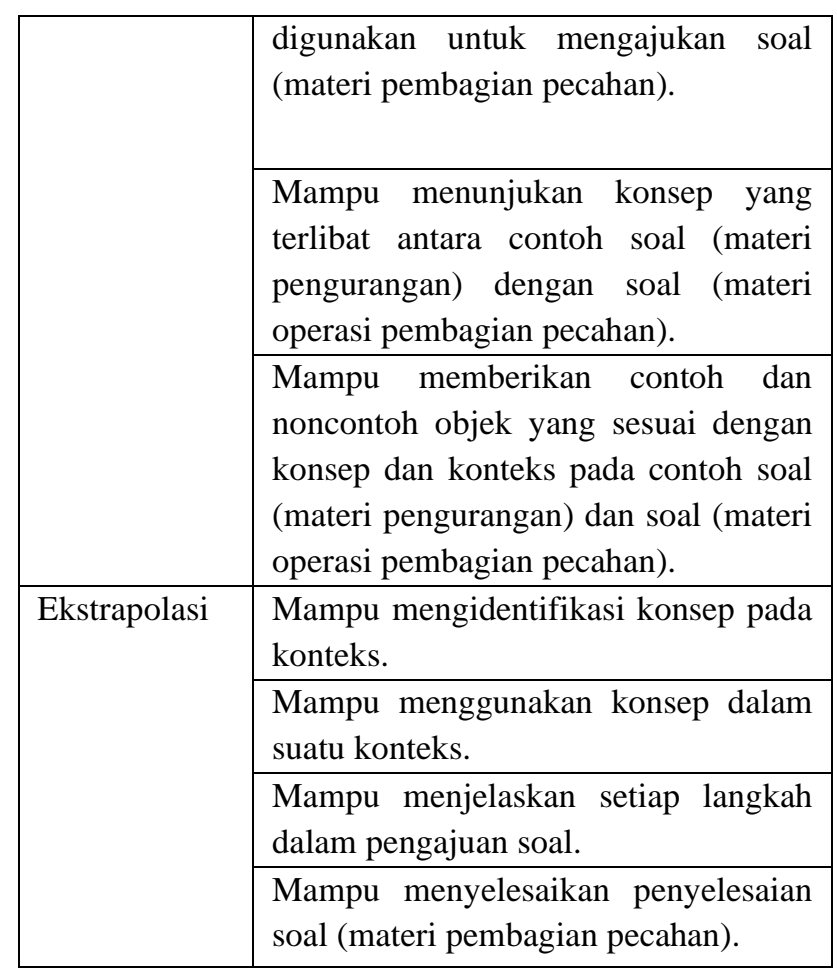

\section{HASIL DAN PEMBAHASAN}

Hasil dan pembahasan mengenai pemahaman konsep pembagian pecahan siswa SMP kelas VIII berdasar tugas pengajuan soal analogis diperoleh melalui analisis data yang dilakukan. Berikut rincian hasil dan pembahasan pada penelitian ini:

\section{Hasil Penelitian}

Secara umum semua subjek mampu mengajukan soal, tetapi dari hasil analisis dapat diketahui bahwa terdapat kesamaan dan perbedaan setiap subjek dalam mengajukan soal analogis. Pada hasil penelitian akan dijabarkan pada setiap komponen pemahaman untuk setiap subjek.

\section{Subjek 1}

Di bawah ini merupakan hasil jawaban pada Tes Pemahaman Konsep subjek 1.

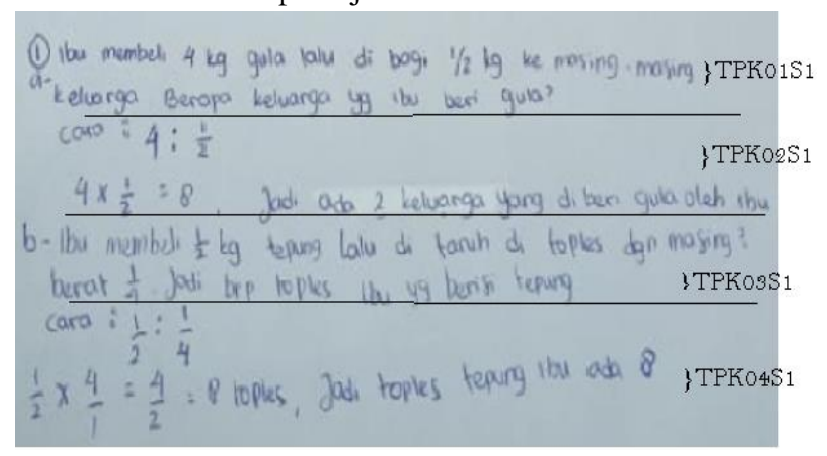

Gambar 1. Lembar Jawaban TPK subjek 1

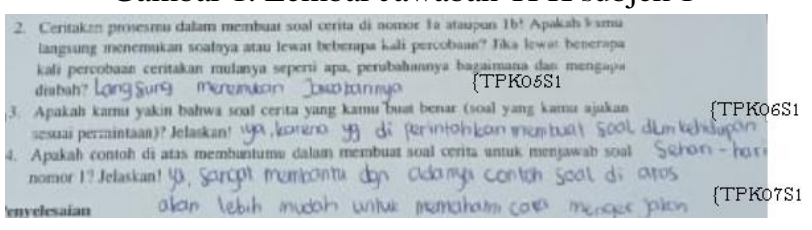

Gambar 2. Lembar Jawaban TPK subjek 1 a. Penerjemahan

Berikut hasil wawancara dengan subjek 1 pada komponen penerjemahan.
$\mathrm{P} \quad$ : Apakah sebelum mengajukan soal kamu mengingat kembali konsep yang pernah kamu pelajari sebelumnya?
S111 : Iya.
P : Dapatkah kamu menjelaskan konsep tersebut?

S112 : Konsep dasar dari pembagian pecahan dengan merubah menjadi perkalian dan pembaginya dibalik. Pada operasi pembagian bilangan pecahan itu dibalik pembaginya setelah itu dikalikan, saya ingatnya dulu saat mengerjakan soal seperti itu, setelah itu untuk pecahan bisa ditulis pada bentuk $\frac{a}{b}$ sifat dari operasi penjumlahan dan pengurangan bilangan pecahan harus disamakan dahulu penyebutnya, setelah itu untuk perkalian pecahan antar pembilang dan penyebut langsung dikalikan tanpa memperhatikan pembilang yang sama, selanjutnya pada operasi pembagian pecahan seperti yang saya jelaskan sebelumnya.

Berdasarkan jawaban dan wawancara dengan subjek 1 didapat bahwa subjek tidak sepenuhnya mampu menjelaskan ulang konsep pembagian pecahan dan konsep pengurangan baik lisan maupun tulis. Pada [TPK05S1] subjek menjelaskan bahwa ia langsung menemukan jawabannya tanpa melalui proses tertentu. Subjek tidak mampu menjelaskan secara tulis konsep yang telah dipelajari sebelumnya, sedangkan pada pernyataan subjek pada [S112] subjek mampu menjelaskan kembali konsep yang telah dipelajari sebelumnya secara lisan.

Konsep yang dijelaskan secara lisan oleh subjek merupakan sifat operasi pembagian atau prosedur penyelesaian operasi pembagian. Subjek tidak mampu menjelaskan konsep dasar pembagian secara umum serta tidak mampu menjelaskan konsep dasar operasi pengurangan.

b. Penafsiran

Berikut hasil wawancara dengan subjek 1 pada komponen menafsirkan.

$\mathrm{P} \quad$ : Apakah kamu membaca petunjuk dan memahami petunjuk pada lembar tes?

S113 : Iya saya membaca petunjuk dan memahami petunjuk tersebut.

P : Materi apa yang pertamakali kamu pikirkan saat membaca soal?

S114 : Pada contoh soal materi pengurangan, pada soal materi operasi pembagian pecahan. 
P : Mengapa materi tersebut yang kamu pikirkan? Apakah ada kaitannya dengan soal yang kamu ajukan?

S115 : Karena terlihat jelas pada soal, kaitannya karena sama-sama merupakan operasi bilangan, menurut saya tidak ada kaitannya operasi pengurangan dengan operasi pembagian

P : Pada lembar jawaban, soal yang kamu ajukan menggunakan tepung dan gula, bagaimana kamu menentukan barang tersebut dalam soal yang diberikan? Apakah ada barang lain untuk menggantikan tepung dan gula?

S116 : Karena tepung dan gula bisa di gunakan pada pecahan $1 / 2$, dan $1 / 4$, untuk barang lain bisa menggunakan beras, buah, minyak, dan kain.

P : : Apakah contoh soal mebantumu dalam mengajukan soal? Bantuan seperti apa yang diberikan contoh soal?

S117 : Iya, sangat membantu karena dapat membantu saya dalam menentukan barang dalam angka yang ditentukan, setelah itu saya hubungkan ke konsep pembagian pecahan.

Berdasarkan jawaban dan wawancara subjek 1 didapat bahwa subjek mampu memahami petunjuk soal, tetapi tidak mampu memahami hubungan perintah soal dengan jawaban pada contoh soal untuk dapat menggunakan konsep tersebut dalam tugas pengajuan soal. Hal tersebut dibuktikan bahwa subjek tidak mengidentifikasi kesamaan atau perbedaan antara contoh soal (konsep operasi pengurangan) dengan soal (konsep operasi pembagian pecahan).

Berdasarkan jawaban dan wawancara, subjek 1 mampu menyebutkan dan menggunakan materimateri yang terkandung dalam contoh soal dan soal. Pada [S114] subjek mampu menyebutkan materi yang terkadung dalam TPK dan menggunakannya dalam pengajuan soal.

Pada jawaban yang subjek tulis [TPK05S1] menyatakan bahwa ia tidak melalui proses tertentu dalam mengajukan soal, yang berarti subjek 1 tidak menghubungkan konsep dasar pembagian dengan contoh soal. Hal tersebut bertolak belakang saat subjek diwawancarai, subjek memahami ide utama dari tes yang diberikan, yaitu mengajukan soal dengan menghubungkannya pada contoh soal [S117]. Subjek tidak menghubungkan jawaban pada contoh soal kedalam soal yang diajukan, karena pada konsep dasar pembagian ia tidak menjelaskan keterkaitan kedua konsep dimana pembagian merupakan pengurangan berulang hingga hasil pengurangan menjadi nol dengan syarat bilangan pembagi harus lebih kecil dari pada yang dibagi sesuai dengan permasalahan pada TPK.

Berdasarkan jawaban yang telah dipaparkan serta berdasarkan wawancara, contoh soal dapat membantu subjek dalam menentukan objek barang yang digunakan pada pengajuan soal. Subjek dibantu oleh jawaban contoh soal operasi pengurangan dan menganalogikannya pada pengajuan soal operasi pembagian. Pada [S116] subjek telah mampu mengenali dan menggunakan konteks pada konsep pembagian pecahan. Pada soal yang diajukan subjek menggunakan objek gula dan tepung, objek-objek tersebut digunakan bersandar pada kehidupan seharihari dimana objek yang dipilih sering dijumpai pada satuan pecahan $\left(\frac{1}{2}\right.$, dan $\left.\frac{1}{4}\right)$, selain itu subjek juga mampu memberikan contoh objek lain yang sesuai dengan konteks.

c. Ekstrapolasi

Berikut merupakan kutipan wawancara subjek 1 pada komponen ekstrapolasi.

$\mathrm{P}$ : Bagaimana prosesmu dalam mengajukan soal tersebut?

S118 : Pertama saya menentukan barang yang sesuai terlebih dahulu setelah itu menulis jumlah barang, lalu mengitung penyelesaian, setelah itu saya mengajukan soal.

P : Coba perhatikan penyelesaian jawabanmu apakah menurutmu penyelesaian dari soal tersebut sudah benar?

S119 : Maaf itu salah, saya kurang teliti.

$\mathrm{P}$ : Dapatkah kamu menyebutkan penyelesaian yang tepat dari soal?

$\mathrm{S} 120$ : 1a delapan, $1 \mathrm{~b}$ dua.

Berdasarkan jawaban dan wawancara subjek 1 didapat bahwa subjek mampu mengidentifikasi, menggunakan, dan menuangkan konsep pada pengajuan soal. Pada jawaban yang dipaparkan, subjek menjelaskan bahwa contoh soal membantunya dalam menentukan cara untuk mengajukan soal (sesuai dengan komponen sebelumnya). Dari contoh soal subjek 1 terbantu dalam menentukan proses mengerjakan dan dapat menjelaskan proses pengajuan soal [S118].

Subjek mampu mengidentifikasi konsep pada konteks serta mampu menggunakan konsep dalam suatu konteks, hal tersebut dapat dilihat dari soal yang diajukan. Subjek dinyatakan tepat dalam menggunakan konsep pecahan dan konsep pembagian.

Penyelesaian soal pada [TPK02S1] dan [TPK04S1] tidak tepat, tetapi subjek menjelaskan pada [TPK06S1] bahwa ia yakin penyelesaian dari 
soal yang diajukan sudah tepat. Berdasarkan penjelasan subjek [S119] dapat diketahui bahwa subjek 1 tidak melakukan pengecekan kembali, akibatnya terdapat kesalahan saat menjawab penyelesaian dari soal yang diajukan, akan tetapi pada [S120] subjek 1 mampu menyebutkan jawaban yang benar saat diwawancarai.

\section{Subjek 2}

Di bawah ini merupakan hasil jawaban pada Tes Pemahaman Konsep Subjek 2.

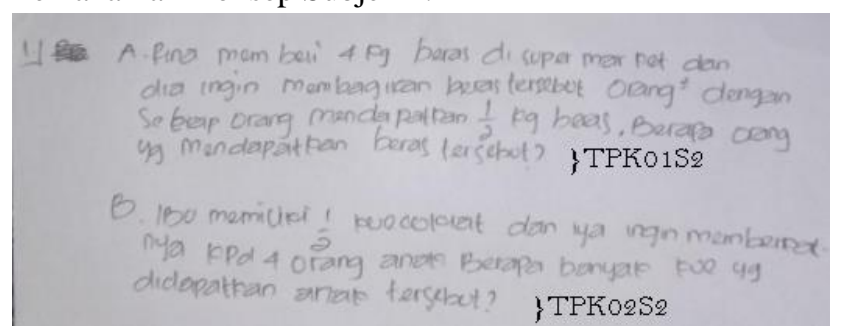

Gambar 3. Lembar Jawaban TPK subjek 2

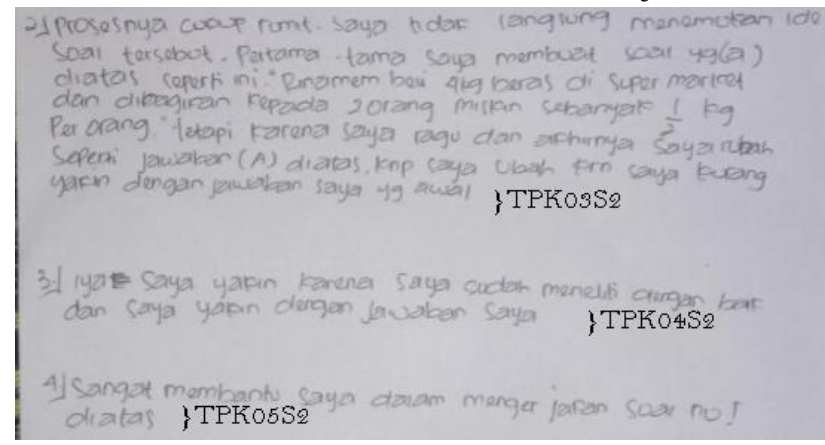

Gambar 4. Lembar Jawaban TPK subjek 2

a. Penerjemahan

Berikut kutipan wawancara yang dilakukan oleh Subjek2 terkait komponen penerjemahan.

P : Apakah sebelum kamu mengajukan soal, kamu mengingat kembali materi yang pernah kamu pelajari sebelumnya?

S211 : Saya tidak mengingat materi apapun.

P : Jelaskan apakah kamu yakin soal yang kamu ajukan sesuai dengan soal yang diminta?

S212 : Saya yakin soal a saya benar, tetapi saya tidak yakin dengan jawaban saya no $1 b$.

Berdasarkan jawaban dan wawancara subjek 2 didapat bahwa ia kurang mampu memahami konsep pecahan yang digunakan pada soal yang diajukan. Hal tersebut dapat dilihat dari soal yang diajukan subjek 2 [TPK01S2] sudah tepat, tetapi pengajuan soal [TPK02S2] tidak sesuai dengan soal yang diminta.

Subjek menjelaskan pada [S211 dan S212] bahwa ia cukup yakin dengan jawabannya pada pengajuan soal [TPK01S2], tetapi tidak yakin dengan pengajuan soal [TPK02S2]. Hal tersebut membuktikan bahwa subjek memahami konsep operasi pembagian tetapi tidak memahami konsep pecahan, meskipun tidak mampu menjelaskan ulang secara verbal maupun tulisan konsep yang ia gunakan pada pengajuan soal. Maka dapat dinyatakan bahwa subjek tidak mampu menyatakan ulang konsep materi yang telah dipelajari sebelumnya.

b. Penafsiran

Berikut kutipan wawancara yang dilakukan oleh subjek 2 terkait komponen penafsiran.

$\mathrm{P} \quad$ : Apakah kamu membaca petunjuk dan memahami petunjuk pada lembar tes?

S213 : Iya, saya sudah membaca dan memahami petunjuk tersebut, setelah itu saya mencerna contoh soal.

P : Materi apa yang pertamakali kamu pikirkan saat membaca soal?

S214 : Materi yang saya pikirkan setelah membaca soal tersebut yaitu pembagian bilangan pecahan.

P : Mengapa materi tersebut yang kamu pikirkan? Apa ada kaitannya dengan contoh soal?

S215 : Menurut saya tidak ada kaitannya karena konsep pengurangan dengan pembagian konsepnya berbeda, saya hanya meniru contoh soal di atas tanpa mengaitkan konsep.

P : Pada lembar jawaban, soal yang kamu ajukan menggunakan beras dan cokelat, bagaimana kamu menentukan barang tersebut dalam soal yang diberikan?

S216 : Saya memilih benda yang dapat dibagi dan dipotong-potong.

$\mathrm{P}$ : Apakah ada barang lain untuk menggantikan beras dan cokelat?

S217 : Gula pasir dan buah-buahan.

$\mathrm{P}$ : Apakah contoh soal mebantumu dalam mengajukan soal?

S218 : Iya membantu.

$\mathrm{P} \quad$ : Bantuan seperti apa yang diberikan contoh soal?

S219 : Contoh soal membantu mengajukan soal dalam menyusun kata-kata dalam mengajukan soal.

Berdasarkan jawaban dan wawancara subjek 2 didapat bahwa, subjek mampu memahami petunjuk soal tetapi tidak mampu memahami hubungan perintah soal dengan jawaban contoh soal. Keterkaitan antara petunjuk, jawaban contoh soal, dan soal dapat digunakan untuk mengaitkan konsep yang berhubungan dalam tugas pengajuan soal.

Pada jawaban yang subjek tulis [TPK05S2] menyatakan terbantu dengan adanya contoh soal, yang berarti subjek 2 menghubungkan kesamaan sifat dari jawaban contoh soal dengan soal yang diajukan. Subjek memahami ide utama dari tes yang diberikan, yaitu mengajukan soal dengan menghubungkannya 
pada contoh soal [S218]. Subjek tidak mengaitkan konsep yang terkandung pada jawaban contoh soal dengan pengajuan soal karena pada [S215] ia menjelaskan bahwa tidak ada kaitannya konsep pengurangan dengan konsep pembagian.

Berdasarkan jawaban dan wawancara, subjek 2 kurang mampu menyebutkan dan menggunakan materi-materi yang terkandung dalam contoh soal dan soal. Pada [S214] subjek mampu menyebutkan materi yang terkadung dalam soal TPK, tetapi tidak mampu menyebutkan materi yang terkandung pada contoh soal.

Berdasarkan jawaban dan wawancara, subjek mampu mengklasifikasikan objek-objek menurut sifat-sifatnya dan menglasifikasi objek sesuai dengan konteks. Hal tersebut dibuktikan dari jawaban subjek dan wawancara [S216 dan S217] yang menyatakan bahwa beras dan cokelat merupakan benda yang dapat dibagi sesuai dengan soal yang diminta dan mampu menyebutkan barang lain untuk menggantikan objek barang yang dipilih pada soal yang diajukan.

c. Ekstrapolasi

Berikut merupakan kutipan wawancara subjek 2 pada komponen ekstrapolasi.

$\mathrm{P}$ : Bagaimana prosesmu dalam mengajukan soal tersebut?

S220 : Saya hanya mengajukan soal dengan meniru contoh soal saja setelah itu saya memilih barang yang sesuai dengan biangan pada soal, serta saya mengajukan pertanyaan sesuai dengan pikiran saya.

P : Apakah sebelum mengajukan soal kamu mencari penyelesaian soal terlebih dahulu?

S221 : Saya tidak mencari penyelesaiannya.

Berdasarkan jawaban dan wawancara subjek 2 didapat bahwa subjek kurang memenuhi komponen ekstrapolasi karena salah satu soal yang diajukan tidak sesuai dengan soal yang diminta dalam penulisan bilangan pecahan, tetapi soal yang diajukan [TPK01S2] dan [TPK02S2] sudah sesuai dengan konsep operasi pembagian.

Berhubungan dengan komponen sebelumnya bahwa subjek tidak mampu mengaitkan konsep pada contoh soal dengan soal yang akan diajukan, dan tidak dapat mengungkapkan kaitan konsep soal yang diajukan dengan pegetahuan sebelumnya. Maka dapat dinyatakan bahwa subjek 2 tidak mampu mengidentifikasi konsep pecahan pada konteks, serta tidak mampu menggunakan konsep pecahan dalam pengajuan soal.

Hal tersebut diperjelas dengan jawaban subjek 2 pada [S220] bahwa ia hanya meniru contoh soal, dan menghubungkannya pada materi pembagian (karena soal yang diajukan sesuai materi pembagian). Subjek 2 tidak menyinggung pada materi pecahan karena saat diminta untuk menjelaskan materi yang didapat sebelumnya subjek 2 tidak mengingat materi apapun. Subjek hanya menulis angka pada pengajuan soal sesuai soal yang diminta, saat subjek 2 mengajukan soal operasi pembagian bilangan pecahan dengan bilangan pecahan ia mengalami kebingungan.

Pada jawaban [TPK03S2] subjek menjelaskan prosesnya dalam mengajukan soal dengan mencoba mengajukan soal yang lain terlebih dahulu dan mengubah jawaban pada pengajuan soal bila mengalami kesalahan, yang berarti bahwa soal yang diajukan subjek 2 telah melewati pengecekan kembali. Sejalan dengan [S219 dan S220] subjek menjelaskan bahwa ia mengajukan soal sesuai dengan yang ada dipikirannya. Dari pernyataan subjek 2 dapat diketahui pada tugas pengajuan soal bahwa ia hanya menulis kembali jawaban pada contoh soal kedalam soal lalu mengaitkannya dengan materi operasi pembagian tanpa mencari penyelesaian dari soal yang diajukan [S221]. Subjek 2 tidak mampu menjelaskan pengetahuan yang ada dipikirannya.

\section{Subjek 3}

Di bawah ini merupakan hasil jawaban pada Tes Pemahaman Konsep Subjek3.

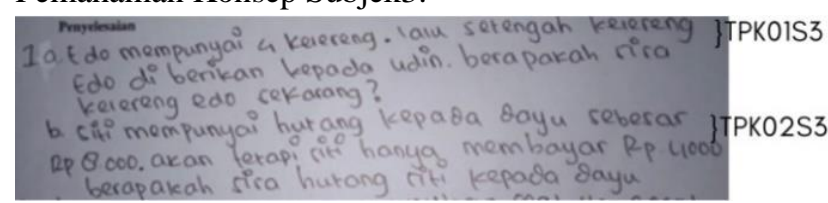

Gambar 5. Lembar Jawaban TPK ubjek 3

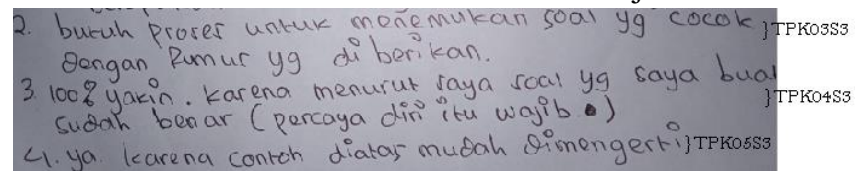

Gambar 6. Lembar Jawaban TPK subjek 3

a. Penerjemahan

Berikut hasil wawancara dengan subjek 3 pada komponen penerjemahan.

$\mathrm{P} \quad$ : Apakah sebelum kamu mengajukan masalah kamu mengingat kembali konsep yang telah kamu pelajari sebelumnya?

S311 : Iya.

P : Dapatkah kamu menjelaskan konsep tersebut?

S312 : Konsep yang saya ingat yaitu pengurangan, agar benda di soal dapat dikurangi maka angka pertama lebih besar dari angka kedua.

$\mathrm{P} \quad$ : Apakah hanya konsep pengurangan saja?

S313 : Iya, karena saya tidak ingat materi pembagian maka saya menggunakan materi pengurangan saja. 
Berdasarkan jawaban dan wawancara subjek 3 didapat bahwa subjek tidak mampu untuk menjelaskan ulang secara verbal maupun tulis konsep yang telah dipelajari sebelumnya. Berdasarkan jawaban subjek 3 [TPK01S3 dan TPK02S3] subjek mengajukan soal menggunakan konsep pecahan, sejalan dengan [S312 dan S313] subjek hanya menjelaskan konsep pengurangan, tetapi konsep operasi pengurangan yang dijelaskan oleh subjek tidak tepat.

Subjek menuturkan bahwa ia sadar bila soal yang diminta merupakan konsep operasi pembagian pecahan tetapi karena tidak mengingat apapun tentang konsep operasi pembagian pecahan maka subjek hanya memberikan penjelasan dengan menggunakan konsep operasi pengurangan.

b. Penafsiran

Berikut kutipan wawancara yang dilakukan oleh subjek 3 terkait komponen penafsiran.

$\mathrm{P} \quad$ : Apakah kamu membaca petunjuk dan memahami petunjuk pada lembar tes?

S314 : Iya, saya sudah membaca dan memahami petunjuk tersebut.

P : Materi apa yang pertamakali kamu pikirkan saat membaca soal?

S315 : Pengurangan dan pembagian.

$\mathrm{P} \quad$ : Apa kaitannya dengan soal yang kamu ajukan?

S316 : Menurut saya tidak ada kaitannya.

P : Pada lembar jawaban, soal yang kamu ajukan menggunakan kelereng dan uang, bagaimana kamu menentukan barang tersebut dalam soal yang diberikan?

S317 : Hanya itu yang saya pikirkan.

$\mathrm{P} \quad$ : Apakah menurutmu benda yang kamu ajukan sudah sesuai?

S318 : Sudah.

$\mathrm{P}$ : Apakah ada barang lain untuk menggantikan kelereng dan uang?

S319 : Tidak ada.

$\mathrm{P} \quad$ : Apakah contoh soal mebantumu dalam mengajukan soal?

S320 : Tidak membantu

Berdasarkan jawaban dan wawancara subjek 3 didapat bahwa subjek mampu memahami petunjuk soal, tetapi tidak mampu memahami hubungan perintah soal dengan jawaban contoh soal. Hal tersebut dibuktikan bahwa subjek tidak mampu mengidentifikasi kesamaan atau perbedaan antara contoh soal (materi operasi pengurangan) dengan soal (materi operasi pembagian pecahan), sesuai dengan jawabannya [S320] bahwa contoh soal tidak membantunya dalam mengajukan soal.

Berdasarkan [S315], subjek mampu menyebutkan materi apa saja yang terkandung pada contoh soal dan soal, tetapi subjek tidak mampu mengaitkan konsep materi yang telah ia sebutkan sesuai pengetahuan sebelumnya.

Berdasarkan [TPK01S3 dan TPK02S3] subjek tidak mampu mengklasifikasikan objek-objek menurut sifat tertentu, kedua objek barang yang dipilih subjek tidak sesuai konteks permasalahan. Berdasarkan penjelasan subjek 3 mengenai konteks soal yang diajukan ia menyatakan bahwa barang yang digunakan telah tepat dan subjek tidak bisa menyebutkan barang lain yang bisa menggantikan konteks barang yang telah diajukan.

c. Ekstrapolasi

Berikut merupakan kutipan wawancara subjek 3 pada komponen ekstrapolasi.

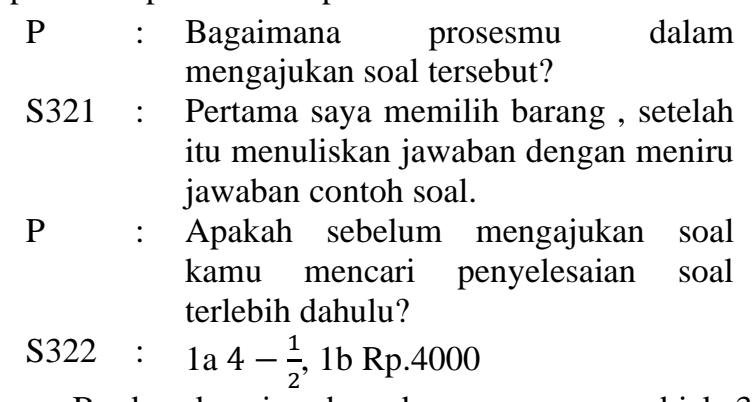

Berdasarkan jawaban dan wawancara subjek 3 didapat bahwa subjek mampu menjelaskan proses dalam mengajukan soal. Subjek menyebutkan bahwa ia melewati beberapa proses dalam pengajuan soal yaitu memilih barang untuk soal yang akan diajukan [S321], setelah itu menuliskan soal yang diajukan dengan meniru penyelesaian dari contoh soal, dan mengganti dengan bilangan yang sesuai dengan soal yang diminta [S321].

Berdasarkan hasil analisis data subjek 3 pada komponen sebelumnya, tidak ada sedikitpun kalimat penjelasan yang menyangkut konsep pecahan. Hal tersebut mencerminkan bahwa subjek tidak memahami konsep operasi pembagian, yang berpengaruh pada pemahaman konsep pecahan karena materi pecahan diajarkan setelah materi pembagian. Subjek 3 tidak memenuhi komponen ekstrapolasi karena berdasarkan soal yang diajukan subjek tidak mampu mengaplikasikan konsep yang telah dipelajari dalam pengajuan soal, tidak mampu mengidentifikasi konsep pembagian pecahan pada konteks, dan tidak mampu menggunakan konsep pembagian pecahan tersebut dalam pengajuan soal.

Ketidakmampuan subjek dalam pengajuan soal diakibatkan karena subjek tidak memahami konsep pembagian pecahan yang telah ia pelajari sebelumnya. Sejalan dengan hal tersebut [S322] subjek menyebutkan penyelesaian dari soal yang ia 
ajukan dengan menggunakan prosedur operasi pengurangan.

\section{Pembahasan.}

Berikut rekapitulasi pemahaman subjek terhadap konsep pembagian pecahan berdasar tugas pengajuan soal analogis pada hasil penelitian.

Table 2. Rekapitulasi Pemahaman Konsep Pembagian Pecahan.

\begin{tabular}{|c|c|c|}
\hline Subjek & $\begin{array}{c}\text { Komponen } \\
\text { Pemahaman }\end{array}$ & Deskripsi \\
\hline \multirow[t]{8}{*}{ Subjek 1} & Penerjemahan & $\begin{array}{l}\text { Subjek } 1 \text { menjelaskan } \\
\text { ulang konsep prosedur } \\
\text { penyelesaian operasi } \\
\text { pembagian secara lisan. }\end{array}$ \\
\hline & \multirow[t]{3}{*}{ Penafsiran } & 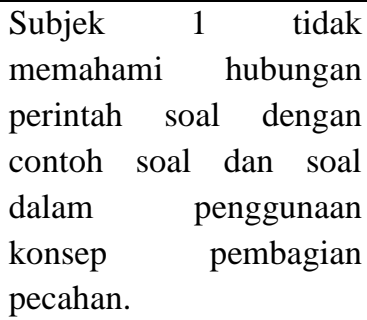 \\
\hline & & $\begin{array}{l}\text { Subjek } 1 \text { menyebutkan } \\
\text { dengan tepat materi yang } \\
\text { terkandung dalam TPK. }\end{array}$ \\
\hline & & $\begin{array}{l}\text { Subjek } 1 \text { menyebutkan } \\
\text { contoh objek yang sesuai } \\
\text { dengan konsep dan } \\
\text { kontes dalam TPK. }\end{array}$ \\
\hline & \multirow[t]{4}{*}{ Ekstrapolasi } & $\begin{array}{l}\text { Subjek } 1 \text { menjelaskan } \\
\text { keterkaitan contoh soal } \\
\text { dalam pengajuan soal. }\end{array}$ \\
\hline & & $\begin{array}{l}\text { Subjek } 1 \text { menggunakan } \\
\text { konsep dalam suatu } \\
\text { konteks dengan tepat. }\end{array}$ \\
\hline & & $\begin{array}{l}\text { Subjek } 1 \text { menjelaskan } \\
\text { langkah pengajuan soal } \\
\text { secara akurat. }\end{array}$ \\
\hline & & $\begin{array}{l}\text { Subjek 1 mengalami } \\
\text { kesalahan dalam } \\
\text { menyelesaikan } \\
\text { penyelesaian soal secara } \\
\text { tulis, namun dengan tepat } \\
\text { menjawab penyelesaian } \\
\text { soal secara lisan. }\end{array}$ \\
\hline \multirow[t]{2}{*}{ Subjek 2} & Penerjemahan & $\begin{array}{lr}\text { Subjek } 2 \text { tidak } & \text { tidak } \\
\text { menjelaskan } & \text { ulang } \\
\text { konsep } & \text { pembagian } \\
\text { pecahan secara lisan dan } \\
\text { tulis. }\end{array}$ \\
\hline & Penafsiran & $\begin{array}{lrr}\text { Subjek } & 2 & \text { tidak } \\
\text { memahami } & & \text { hubungan }\end{array}$ \\
\hline
\end{tabular}

\begin{tabular}{|c|c|c|}
\hline & & $\begin{array}{lrr}\text { perintah } & \text { soal dengan } \\
\text { contoh } & \text { soal dan soal } \\
\text { dalam } & \text { penggunaan } \\
\text { konsep } & \text { pembagian } \\
\text { pecahan. } & \end{array}$ \\
\hline & & $\begin{array}{l}\text { Subjek } 2 \text { menyebutkan } \\
\text { materi dalam soal, dan } \\
\text { tidak menyebutkan } \\
\text { materi dalam contoh soal. }\end{array}$ \\
\hline & & $\begin{array}{l}\text { Subjek } 2 \text { menyebutkan } \\
\text { contoh objek yang sesuai } \\
\text { dengan konsep dan } \\
\text { kontes dalam TPK. }\end{array}$ \\
\hline & \multirow[t]{4}{*}{ Ekstrapolasi } & $\begin{array}{l}\text { Subjek } 2 \text { menjelaskan } \\
\text { keterkaitan contoh soal } \\
\text { dengan pengajuan soal } \\
\text { dalam penentuan objek. }\end{array}$ \\
\hline & & $\begin{array}{l}\text { Subjek } 2 \text { menggunakan } \\
\text { konsep dalam suatu } \\
\text { konteks dengan tepat } \\
\text { pada soal a, namun tidak } \\
\text { dapat } \\
\text { menggunakankonsep } \\
\text { pecahan dalam } \\
\text { pengajuan soal b. }\end{array}$ \\
\hline & & $\begin{array}{l}\text { Subjek } 2 \text { menjelaskan } \\
\text { langkah pengajuan soal } \\
\text { dengan menulis ulang } \\
\text { contoh soal dan } \\
\text { mengaitkan pada konsep } \\
\text { pembagian. }\end{array}$ \\
\hline & & $\begin{array}{l}\text { Subjek } 2 \text { tidak mencari } \\
\text { penyelesaian dari soal } \\
\text { yang diajukan. }\end{array}$ \\
\hline \multirow[t]{4}{*}{ Subjek 3} & Penerjemahan & $\begin{array}{l}\text { Subjek } 3 \text { tidak tidak } \\
\text { menjelaskan } \\
\text { konsep } \begin{array}{r}\text { ulang } \\
\text { pecahan secara lisan dan }\end{array} \\
\text { tulis. }\end{array}$ \\
\hline & \multirow[t]{3}{*}{ Penafsiran } & $\begin{array}{lrr}\text { Subjek } & 3 & \text { tidak } \\
\text { memahami } & \text { hubungan } \\
\text { perintah } & \text { soal dengan } \\
\text { contoh } & \text { soal dan soal } \\
\text { dalam } & \text { penggunaan } \\
\text { konsep } & \text { pembagian } \\
\text { pecahan. }\end{array}$ \\
\hline & & $\begin{array}{lr}\text { Subjek } & \text { tidak } \\
\text { menyebutkan } & \text { materi } \\
\text { dalam contoh } & \text { soal dan } \\
\text { soal. } & \\
\end{array}$ \\
\hline & & $\begin{array}{l}\text { Subjek } 3 \text { tidak dapat } \\
\text { menyebutkan objek yang }\end{array}$ \\
\hline
\end{tabular}




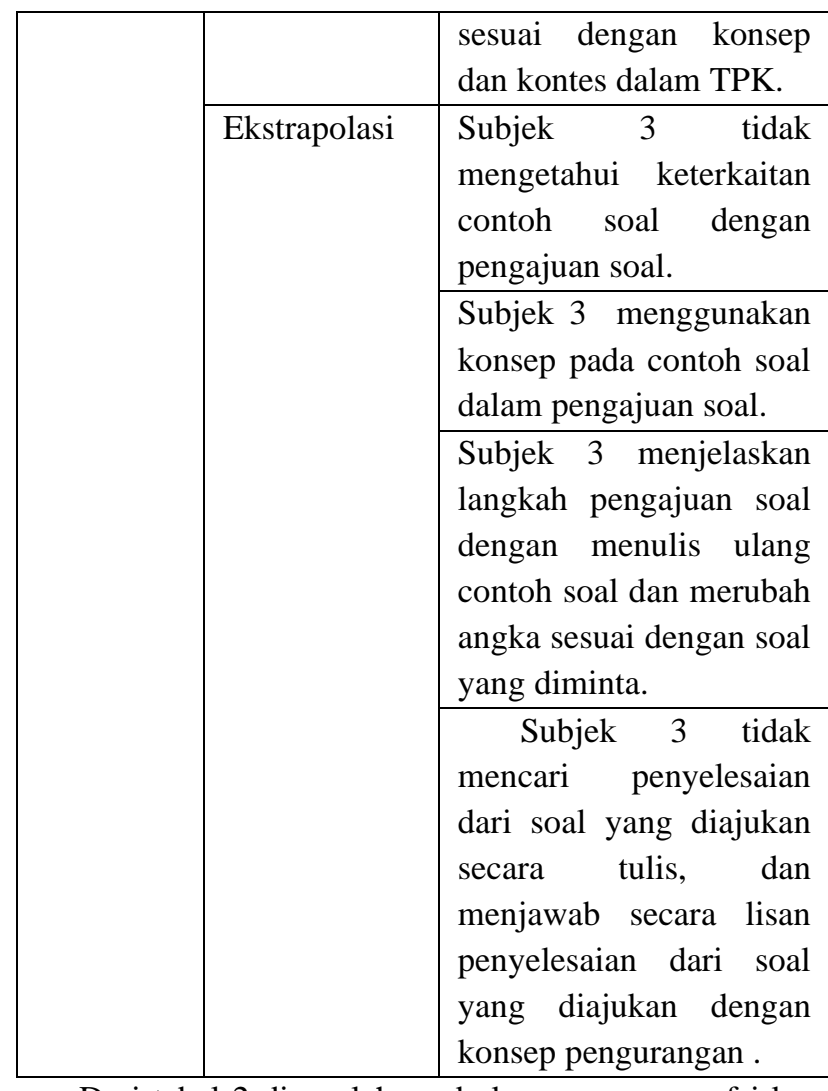

Dari tabel 2 diperoleh, pada komponen menafsirkan setiap subjek mampu mengaitkan berbagai konsep yang telah dipelajari. Hal tersebut ditandai dengan kemampuan subjek dalam menyebutkan materi apa saja yang berhubungan pada lembar tes pemahaman konsep yaitu materi pengurangan, pembagian, dan pecahan, tetapi semua subjek tidak mampu menyatakan hubungan konsep dasar materi pengurangan dengan materi pembagian. Hal tersebut memperkuat temuan Natalia (2020) pada penafsiran siswa tidak memiliki pemahaman yang memadai pada materi prasyarat.

Pada komponen penerjemahan hanya satu subjek yang mampu menjelaskan konsep pecahan. Konsep yang dijelaskan bukan mengenai konsep awal dari konsep operasi pembagian pecahan melainkan sifat operasi pembagian atau prosedur penyelesaian operasi pembagian. Hal ini sesuai dengan pendapat temuan Natalia (2020) bahwa umumnya pada indikator penerjemahan siswa SMP masih sering mengalami kesalahan dalam menjelaskan materi pada soal .

Pada komponen penafsiran dalam tugas pengajuan soal tidak ada subjek yang mampu memahami hubungan perintah soal dengan jawaban contoh soal untuk dapat menggunakan kaitan konsep tersebut dalam mengajukan soal. Hal tersebut dibuktikan bahwa hanya ada satu subjek yang mampu mengidentifikasi perintah soal tanpa mengetahui ide utama dari tes yang diberikan.

Pada perintah soal diharapkan seluruh subjek mampu untuk memahami bahwa jawaban contoh soal materi pengurangan memiliki kaitan dengan materi pembagian. Pada soal TPK subjek diminta mengajukan soal pada materi pembagian dimana bilangan pembagi lebih kecil dari yang dibagi. Subjek dapat mengingat kembali dan mencari keterkaitan antara soal yang diminta (materi pembagian) dengan jawaban pada contoh soal (materi pengurangan), dimana pembagian dengan bilangan pembagi lebih kecil dari pada bilangan yang dibagi dapat didekati dengan pengurangan berulang hingga hasil menjadi nol. Pada pembagian pecahan subjek dituntut untuk menganalogikan pada pengetahuan sebelumnya yaitu metode perkalian dan invers atau dengan pengurangan berulang. Pembagian pecahan dapat pula dianalogikan dengan menginterpretasikan dalam bentuk konteks kehidupan nyata.

Seseorang dikatakan paham konsep bila mampu mengenali konsep tersebut di setiap konteks. Dengan menggunakan analogi subjek dapat menentuan objek saat menginterpretasikan soal kebentuk konteks kehidupan nyata. Terdapat dua subjek yang mampu mengklasifikasikan objek menurut sifat tertentu serta menjelaskan alasan mengapa objek tersebut digunakan dalam tugas pengajuan soal, dan mampu menyebutkan objek lain yang dapat digunakan dalam konteks yang sesuai. Hal tersebut sesuai dengan pendapat Zawawi (2016) seseorang dikatakan menganalogi jika dapat mengidentifikasi hubungan masalah yang dihadapi dengan pengetahuan yang telah dimiliki, dan menggunakan benda-benda nyata yang ada disekitarnya dalam membangun ide untuk merencanakan penyelesaian.

Dalam menemukan kaitan antara contoh soal dengan soal tidak hanya mengenai konsep yang terkandung, tetapi konteks yang digunakan pula. Hanya ada satu subjek yang menggunakan keterkaitan tersebut dalam penentuan objek pengajuan soal. Subjek lainnya dalam menentukan objek pengajuan soal melalui penganalogiaan pada kehidupan nyata. Hal tersebut sejalan dengan pendapat Park (2018) dengan mengajukan soal analogis siswa dapat mengembangkan konteks yang serupa.

Pada komponen ekstrapolasi, hanya satu subjek yang mampu mengaplikasikan konsep kedalam pengajuan soal serta mencari penyelesaian dari soal yang diajukan dengan tepat. Pada penyelesaian di lembar jawaban TPK subjek tersebut mengalami kesalahan karena tidak teliti tetapi ia mampu memberikan jawaban yang benar pada saat di wawancara. Subjek tersebut juga mampu menyebutkan runtutan proses pengajuan soal. Kesalahan kedua subjek lainnya dalam menentukan penyelesaian soal yang diajukan memperkuat temuan Natalia (2020) pada ekstrapolasi beberapa siswa tidak mampu merencanakan solusi penyelesaian, selain itu kesalahan dalam penyelesaian soal disebabkan siswa salah dalam menentukan rumus yang tepat. 
Pada seluruh komponen pemahaman hanya satu subjek yang tidak memenuhi satupun komponen pemahaman konsep hal tersebut karena ia menulis ulang jawaban pada contoh soal dan mengganti dengan bilangan pada soal. Subjek tersebut tidak mampu menghubungkan informasi dari petunjuk soal dengan jawaban contoh soal dan mengaitkannya pada tugas pengajuan soal, serta tidak memahami konsep materi yang telah diajarkan guru sebelumnya. Hasil data tersebut memperkuat pendapat Hutama (2014) pada kelompok rendah kesalahan dalam pemahaman matematika terdapat pada penerjemahan, penafsiran, dan ekstrapolasi. Senada dengan temuan Unaenah dan Sumantri (2019) siswa hanya meniru cara penyelesaian yang diberikan dan kesulitan apabila menemukan soal yang penyelesaiannya berbeda.

Konsep materi yang telah dipelajari sebelumnya berguna dalam pembentukan pemahaman konsep materi selanjutnya. Terdapat satu subjek yang mampu menggunakan dan menjelaskan konsep pembagian pecahan karena telah mampu memahami konsep pembagian, lain halnya pada subjek yang tidak mampu mengajukan soal karena tidak memahami materi pembagian pecahan. Hal tersebut memperkuat pendapat dari Susanto (2013:209) "pemahaman dan penguasaan suatu materi atau konsep merupakan prasyarat untuk menguasai materi selanjutnya".

\section{PENUTUP}

\section{Simpulan}

Berdasarkan kajiaan hasil dan pembahasan dapat dikemukakan simpulan terkait pemahaman konsep pembagian pecahan siswa SMP berikut ini:

a. Pada komponen penerjemahan, hanya ada satu subjek yang mampu menyatakan ulang konsep yang telah dipelajari sesuai dengan konsep yang diajarkan sebelumnya, tetapi konsep yang dijelaskan bukan mengenai konsep awal dari materi pembagian melainkan sifat operasi pembagian atau proses prosedur penyelesaian operasi pembagian. Kedua subjek lainnya tidak mampu menjelaskan konsep yang telah dipelajari sebelumnya.

b. Pada komponen penafsiran, tidak ada subjek yang mampu mencari hubungan perintah soal dengan jawaban contoh soal untuk dapat menggunakan kaitan konsep tersebut dalam tugas pengajuan soal, sedangkan ketiga subjek mampu untuk menyebutkan materi yang berkaitan dengan soal, akan tetapi tidak ada satupun yang dapat menjelaskan keterkaitan konsep materi yang disebutkan. Terdapat satu subjek yang mampu mengenali konsep di setiap konteks, serta terdapat dua subjek yang mampu menyebutkan objek-objek yang sesuai dengan konsep pecahan, kedua subjek tersebut mampu menjelaskan alasan mengenai objek yang digunakan dalam soal yang diajukan, dan menyebutkan benda lain yang dapat digunakan dalam konteks yang sesuai.

c. Pada komponen ekstrapolasi, hanya ada satu subjek yang mampu mengaplikasikan konsep kedalam tugas pengajuan soal, serta mencari penyelesaian dari soal yang diajukan, meskipun pada penyelesaian di lembar jawaban subjek tersebut mengalami kesalahan karena kurang teliti, tetapi ia mampu memberikan jawaban yang benar pada saat di wawancara, selain itu subjek tersebut juga mampu menyebutkan runtutan proses pengajuan soal. Terdapat satu subjek lainnya yang tidak mampu menggunakan konsep pecahan dalam pengajuan soal, tetapi konsep pembagiannya sesuai. Terdapat satu subjek yang tidak memenuhi komponen ekstrapolasi, ketidakmampuan subjek dalam pengajuan soal diakibatkan karena subjek tidak memahami konsep pembagian pecahan yang telah ia pelajari sebelumnya.

d. Berdasarakan penjelasan diatas didapat bahwa melalui tugas pengajuan soal analogis yang dikembangkan bisa digunakan untuk mengetahui tingkat pemahaman konsep yang telah dipelajari sebelumnya.

\section{Saran}

Pemahaman dapat ditingkatkan melalui pemberian tugas pengajuan soal analogis, hal ini berdasar pada hasil penelitian yang diperoleh didapat satu subjek yang mampu menganalogikan sifat-sifat yang berhubungan pada dua permasalahan. Dengan menganalogikan, subjek tersebut mampu mengembangkan konteks, dan memperluas konsep.

Pada pembelajaran guru perlu melatih kemampuan menggunakan analogi agar pemahaman konsep siswa semakin mendalam mengenai materi yang sedang diajarkan, selain itu menggunakan tugas pengajuan soal analogis dalam pelajaran matematika juga dapat membantu guru mengetahui pemahaman siswa pada materi yang sedang diajarkan dan materi yang telah diajarkan sebelumnya.

\section{DAFTAR PUSTAKA}

Aminah, A., \& Kurniawati, K. R. A. 2018. Analisis Kesulitan Siswa Dalam Menyelesaikan Soal Cerita Matematika Topik Pecahan Ditinjau Dari Gender. JTAM, Vol. 2 No. 2, pp. 118-122.

Alghadari, F., \& Kusuma, A. P. 2018. Pendekatan Analogi untuk Memahami Konsep dan Definisi dari Pemecahan Masalah. In Prosiding Seminar Nasional Matematika dan Pendidikan Matematika, Vol. 2 No. 1, pp. 113-122.

Hariyani, S. 2016. Kategorisasi Kesalahan Pemahaman Siswa Terhadap Konsep Operasi Pembagian 
Pecahan. In Prosiding Seminar Nasional LPPM Universitas Kanjuruhan Malang, Vol. 4 No. 1, pp. 409.

Hope, M. 2006. Preservice teacher procedural and conceptual understanding of fractions and the effects of inquiry based learning on this understanding. Unpublished Doctoral Dissertation. Clemson University.

Hutama, H. C. 2014. Pengaruh Pendekatan Problem Posing terhadap Pemahaman Konsep Matematika Siswa, Skripsi Sarjana, Jakarta: Universitas Islam Negeri Syarif Hidayatullah.

Indiati, I. 2005. Strategi Pemberian Tugas Pengajuan Soal (Problem Posing) pada Pembelajaran Materi Pokok Gerak Harmonik Sederhana, Kerja, dan Energi: Studi Kasus. Doctoral dissertation, Universitas Negeri Semarang.

Jihad, A., \& Rosyidi, A. H. 2009. Evaluasi Pembelajaran. Yogyakarta: Multi Press.

Juliangkary, E., \& Zulkifli, Z. 2019. PROFIL PEMAHAMAN KONSEP SISWA KELAS VII MTS. QUR'ANIYAH PADA MATERI PECAHAN MELALUI PEMBELAJARAN FRAMEWORK ELPSA. Media Pendidikan Matematika, Vol. 6 No.1, pp. 30-38.

Kapur, M. 2015. The preparatory effects of problem solving versus problem posing on learning from instruction. Learning and instruction, pp. 23-31.

Kemdikbud. 2014. Peraturan Menteri Pendidikan Dan Kebudayaan Republik Indonesia Nomor 58 Tahun 2014 Tentang Kurikulum 2013 Sekolah Menengah Pertama/Madrasah Tsanawiyah. Jakarta: Kemdikbud.

Kristayulita, K. 2015. Penalaran analogi siswa berdasarkan tahapan Clement. In Prosing Seminar Nasional Matematika dan Pendidikan Matematika UNY Jurusan Pendidikan Matematika Fakultas Matematika dan Ilmu Pengetahuan Alam Universitas Negeri Yogyakarta, pp.799-806.

Lestari, K. E., \& Yudhanegara, M. R. (2015). Penelitian pendidikan matematika. Bandung: PT Refika Aditama, Vol. 2 No. 3.

Loc, N. P., \& Uyen, B. P. 2014. Using Analogy in Teaching Mathematics: An Investigation of Mathematics Education Students in School of Education-Can Tho University. International Journal of Education and Research, Vol. 2 No.7, pp. 91-98.

Mawaddah, S., \& Maryanti, R. 2016. Kemampuan pemahaman konsep matematis siswa SMP dalam pembelajaran menggunakan model penemuan terbimbing (discovery learning). Edu-Mat: Jurnal Pendidikan Matematika, Vol. 4 No.1.
Mestre, J. P. 2002. Probing adults' conceptual understanding and transfer of melearning via problem posing. Journal of Applied Developmental Psychology, Vol. 23 No.1, pp. 9-50.

Mulyani, A., Indah, E. K. N., \& Satria, A. P. 2018. Analisis Kemampuan Pemahaman Matematis Siswa SMP pada Materi Bentuk Aljabar. Mosharafa: Jurnal Pendidikan Matematika, Vol. 7 No.2, pp. 251-262.

Mundiri. 2012. Logika. Bandung: PT RajaGrapindo Persada.

Natalia, S. 2020. Analisis Pemahaman Siswa Terhadap Matematika Ditinjau Dari Pengerjaan Soal Pada Materi Bangun Ruang. Wacana Akademika, Vol. 4 No.2, pp. 148-159.

NCTM. 2000. Principles and Standards for School Mathematics. The United State of America.

Ningrum, R. K., \& Rosyidi, A. H. 2013. Profil Penalaran Permasalahan Analogi Siswa Sekolah Menengah Pertama Ditinjuau Dari Perbedaan Gender. Jurnal Mahasiswa Teknologi Pendidikan, Vol. 3 No.2.

Park, Mimi. 2018. Pemahaman Konsep Statisika Melalui Kegaitan Mengemukakan Masalah Secara Analogi. Jurnal Of Educational Research in Mathematics, Vol. 22 No.1, pp. 101-115.

Peraturan Menteri Pendidikan dan Kebudayaan No 24 Tahun 2016 Tentang Kompetensi Inti dan Kompetensi Dasar Pelajaran pada Kurikulum 2013 pada Pendidikan Dasar dan Pendidikan Menengah. Jakarta: Kemendikbud.

Racmawati, D. A. 2020. Analisis Pemahaman Konsep Sistem Persamaan Linear Dua Variabel Berdasarkan Teori APOS Ditinjau Dari Gaya Kognitif ImpulsifReflektif. Surabaya. Skripsi yang tidak dipublikasikan.

Rosyidi, A. H. 2020. PEMAHAMAN MAHASISWA CALON GURU PADA ANALOGI PROSEDUR MENYELESAIKAN PERSAMAAN KUADRAT DENGAN MEMFAKTORKAN. AKSIOMA: Jurnal Program Studi Pendidikan Matematika, Vol. 9 No.3, pp. 641-650.

Ruslan, R., Bernard, B., \& Akbar, E. A. 2019. Deskripsi Pemahaman Konseptual Matematika Siswa SMP IT Wahdah Islamiyah pada Materi Pecahan Ditinjau dari Gaya Belajar Visual. Issues in Mathematics Education (IMED), Vol. 1 No.1, pp. 12-17.

Siswono, Tatag Y. E. 2008. Model Pembelajaran Matematika Berbasis Pengajuan dan Pemecahan Masalah Untuk Meningkatkan Kemampuan Berpikir Kreatif. Surabaya: Unesa University Press.

Shadiq, F. 2009. Model-Model Pembelajaran Matematika SMP. Yogyakarta: P4TK Matematika Depdiknas.

Sulaiman, F., Desfitri, R., \& Wahyuni, Y. 2019. Error Analysis in Solving Mathematical Problems in Class 
X MIA Students of SMAN 1 Koto Baru Dharmasraya. Abstract of Undergraduate, Faculty of Education, Bung Hatta University, Vol. 1 No.1.

Susanto, Ahmad. 2013. Teori Belajar dan Pembelajaran di Sekolah Dasar. Jakarta: Kencana Prenamedia Group.

Suwarto, S. 2018. Konsep Operasi Bilangan Pecahan melalui Garis Bilangan. Mosharafa: Jurnal Pendidikan Matematika, Vol. 7 No.3, pp. 327-336.

Tawil, M., \& Rusdiana, D. 2011. Efektivitas Pembelajaran Berbasis Simulasi Komputer Pada Topik Superposisi Gelombang Untuk Meningkatkan Pemahaman Konsep Mahasiswa. Jurnal Sains dan Pendidikan Fisika, Vol. 7 No.2.

Thompson, D. R dan Bleiler,S. 2013.Multidimenssional Assessment of CCSSM. Teaching Children Mathematis, Vol.19 No.5. pp. 292-300.
Unaenah, E., \& Sumantri, M. S. 2019. Analisis Pemahaman Konsep Matematis Siswa Kelas 5 Sekolah Dasar Pada Materi Pecahan. Jurnal Basicedu, Vol. 3 No.1, pp. 106-111.

Usiskin, Z. 2012. What Does it Mean to Understand Some Mathetmatics?.Makalah. Disampaikan dalam seminar 12th International Congress on Mathematical Education di Seoul.

Yulianingsih, A., Febrian, Dwinata, A. 2018. Analisis Kesalhan konsep pecahan pada siswa kelas VII A SMP Negeri 13 Satu Atap Tanjungpinang. Mosharafa: Jurnal Pendidikan Matematika, Vol. 7 No.2, pp. 199206.

Zawawi, I. 2016. Berpikir Analogis Siswa SMP Dalam Menyelesaikan Masalah Matematika Ditinjau Dari Kemampuan Matematika. Tersedia: Berpikir Analogis Siswa SMP Dalam Menyelesaikan Masalah Matematika Ditinjau Dari Kemampuan Matematika (ums.ac.id). Diakses 24 Januari 2021. 